\title{
Hanefî Mezhebine Göre Talakın Gizlenmesi Durumunda İddetin Başlangıc1: Meşâyih Fetvasının Müftâ Bih Hale Geliş Süreci
}

\section{Beginning of 'Idda ( The Waiting Period After Divorce) in Case of Hiding Divorce According to Hanafi Sect: Process of Returning of the Mashāyikh's Fatwa to "Mufta Bih"}

\section{Dr. Öğr. Üyesi Mustafa ATEŞ}

Dumlupınar Üniversitesi, İslami İlimler Fakültesi, Temel İslam Bilimleri Anabilim Dalı

Asst. Prof., Dumlupinar Uni., Faculty of Islamic Sciences, Department of Basic Islamic Sciences, Kutahya, Turkey.

mustafa.ates@dpu.edu.tr

(iD) 0000-0001-7449-5454

\begin{tabular}{lcc}
\multicolumn{2}{c}{$\begin{array}{c}\text { Makale Bilgisi / Article Information } \\
\text { Makale Türü / Article Type }\end{array}$} & Araştırma Makalesi / Research Article \\
Geliş Tarihi / Received & Kabul Tarihi / Accepted & Yayın Tarihi / Published \\
21 Mayıs / May 2021 & 31 Ağustos / August 2021 & 23 Eylül / September 2021
\end{tabular}

Atıf Bilgisi / Cite as:

Ateş, Mustafa. "Hanefî Mezhebine Göre Talakın Gizlenmesi Durumunda İddetin Başlangıcı: Meşâyih Fetvasının Müftâ Bih Hale Geliş Süreci”, Eskişehir Osmangazi Üniversitesi İlahiyat Fakültesi Dergisi 8/2 (Eylül 2021), 94-110.

http://doi.org/1051702/esoguifd.940736

Intihal / Plagiarism: Bu makale, en az iki hakem tarafından incelenmiş ve intihal içermediği teyit edilmiştir. / This article has been reviewed by least two referees and scanned via a plagiarism software.

Copyright @ Published by Eskişehir Osmangazi Üniversitesi, İlahiyat Fakültesi /Eskişehir Osmangazi University, Faculty of Theology Bütün hakları saklıdır. / All right reserved. https://dergipark.org.tr/tr/pub/esoguifd

CC BY-NC 4.0 This paper is licensed under a Creative Commons Attribution-NonCommercial License

Etik Beyanı / Ethical Statement: Bu çalışmanın hazırlanma sürecinde bilimsel ve etik ilkelere uyulduğu, yararlanılan tüm çalışmaların kaynakçada belirtildiği ve bu araştırmanın desteklenmesi için herhangi bir dış fon almadıkları yazar tarafından beyan olunur / It is declared by the author that scientific and ethical principles have been followed while carrying out and writing this study; that all the sources used have been properly cited; that no external funding was received in support of the research. 


\section{Hanefî Mezhebine Göre Talakın Gizlenmesi Durumunda İddetin Başlangıc1: Meşâyih Fetvasının Müftâ Bih Hale Geliş Süreci}

Öz • Talakın sonuçlarından biri olan iddet, nikâh bağının sona ermesiyle birlikte kadının beklemesi gereken süre anlamına gelmektedir. Normal şartlarda boşanma durumunda iddet talakla birlikte, ölüm durumunda ise vefatın akabinde başlar. Tek taraflı irade beyanıyla meydana geldiği için talakın kadına haber verilmesi gerekmez. Ancak kadından talakın gizlenmesi durumunda iddetin talaktan itibaren başlaması bir taraftan kadının nafaka ve süknâ gibi bazı haklarının kaybına sebep olmakta diğer taraftan da karı ile koca arasında muvâzaa yapılmak suretiyle birtakım yasak fiillerin meşrû hale getirilme ihtimali ortaya çıkmaktadır. Söz konusu mahzurlar dikkate alınarak Hanefî mezhebi içerisinde mütekaddimûn döneminde çeşitli görüşler ileri sürülmüştür. Bu çalışmada, talakın gizlenmesi durumunda iddetin başlangıcına dair meşâyihin fetvası ve bu fetvanın Hanefî mezhebinde müftâ bih hale geliş süreci incelenmektedir.

Anahtar Kelimeler: İslam Hukuku, Meşâyih, Fetva, Talak, İddet.

Beginning of Idda ( The Waiting Period After Divorce) in Case of Hiding Divorce According to Hanafi Sect: Process of Returning of the Mashāyikh's Fatwa to "Mufta Bih"

Abstract 'Idda, one of the consequences of divorce, means the period to be waited by the woman after the divorce. Under normal circumstances, in the case of divorce, 'Idda begins with divorce, and in case of death, after death. The woman does not have to be notified of the divorce. Because divorce takes place with the one-sided declaration of will. However, if the divorce from the woman is hidden and if 'Idda begins after the divorce, it causes the woman to lose some of her rights such as alimony and home. On the other hand, with the collusion between husband and wife, there is a possibility that some prohibited acts may become legitimate. Considering these problems, various opinions were put forward in the first period within the Hanafi school. In this study, if the divorce is not informed to the woman, the mashāyikh's fatwa regarding the beginning of the 'Idda and the becoming "mufta bih" of this fatwa is examined.

Keywords: İslamic Law, Mashāyikh, Fatwa, Divorce, 'Idda.

\section{Giriş}

İslâm hukukuna göre talak, kocanın tek taraflı irade beyanıyla ve belirli lafızlarla nikâh akdini sona erdirmesi olarak tanımlanmaktadır. ${ }^{1}$ Buna göre koca ister vicâhî olsun isterse giyabında

\footnotetext{
${ }^{1}$ Çeşitli talak tanımları için bk. Alâüddîn Ebû Bekr b. Mes'ûd b. Ahmed el-Kâsânî, Bedâi 'u's-sanâi ' fi tertîbi'ş-şerâi (Dârü'l-Kütübi'l-i̇lmiyye, 1986), 3/88; Ebü'l-Hasen Burhânüddîn Alî b. Ebî Bekr b. Abdilcelîl el-Fergânî elMergînânî, el-Hidâye fi șerhi Bidâyeti'l-mübtedî, thk. Talâl Yûsuf (Beyrut: Dâru İhyâi't-Türâsi'l-Arabî, ts.), 1/221; Ebü'l-Fazl Mecdüddîn Abdullâh b. Mahmûd b. Mevdûd el-Mevsılî, el-İhtiyâr li-ta'lîli'l-Muhtâr, thk. Mahmud Ebû
} 
Ateş, Hanefî Mezhebine Göre Talakın Gizlenmesi Durumunda İddetin Başlangıcı: Meşâyih Fetvasının Müftâ Bih ...

olsun, talak lafızlarından biriyle ya da talak anlamına gelen kinayeli lafızlarla karısını boşayabilir. Başka bir ifadeyle erkeğin karısını haber vermeden boşaması geçerlidir, talakın gerçekleşmesi için kadının boşandığından haberdar olması şart değildir. Söz gelimi koca bir kâğıda ya da yere veya duvara (günümüz şartlarında örneğin telefonun ekranına), boşamaya niyet ederek karısını boşadığını yazsa, o anda boşanmış olur. Karısının bu yazıyı görüp görmemesi önemli değildir. Veyahut başka bir şehirde bulunan karısına onu boşadığını haber veren adresli bir mektup yazsa, mektup karısına ulaşmasa bile bu mektubu yazdığı andan itibaren boşanmış olur. ${ }^{2}$

Talakın sonuçlarından biri olan iddet ise, nikah bağının sona ermesi durumunda kadının beklemesi gereken süre anlamına gelmektedir. ${ }^{3}$ İddet, boşanma durumunda talakın akabinde, ölüm durumunda ise vefatla birlikte başlar. ${ }^{4}$ Ancak tek taraflı irade beyanıla gerçekleşmesi sebebiyle talakın gizlenmeye elverişli olması, normal şartlarda yasaklanmış olan bazı tasarruflara imkân vermektedir. Bu çerçevede tartışılan konulardan biri, beşinci kadınla ve boşanan kadının kız kardeşiyle nikâh meselesidir. İslam hukukuna göre bir kişinin beşinci kadını ya da karısının kız kardeşini nikâhlaması mümkün değildir. Yine bununla alakalı olarak dört karısı olup bunlardan birini boşayan ve başka bir kadınla evlenmek isteyen ya da boşadığı karısının kız kardeşiyle evlenmek isteyen erkeğin, evlenmeden önce boşadığı karısının iddetini beklemesi gerekir. ${ }^{5}$ Dört karısı olup da bunlardan birini daha önce boşadığını ve iddet süresinin bittiğini iddia eden bir kimse, iddet süresini beklemeden başka bir kadınla ya da boşadığını iddia ettiği karısının kız kardeşiyle nikâh kıyabilir. Çünkü iddet süresi olarak bekleyeceği bir zamandan daha önce karısını boşadığını ifade etmektedir. Dolayısıyla bu durumda karısının iddet süresi de dolmuş olmaktadır. Yine talakın gizlenmesi durumunda iddetin talaktan itibaren başladığı kabul edilirse, dört karısı olan bir kişi bunlardan birini boşayıp iddeti dolduğunda -hangisini boşadığını haber vermediği

Dakîka (Matbaatü'l-Halebî, 1937), 3/121; Muhammed b. Ferâmurz Molla Hüsrev, Dürerü'l-hükkâm şerhu Gureri'lahkâm (Dâru İhyâi'l-Kütübi'l-Arabiyye, ts.), 1/358; Halil İbrahim Acar, "Talak", Türkiye Diyanet Vakfi İslâm Ansiklopedisi (İstanbul: TDV Yayınları, 2010), 39/496.

${ }^{2}$ bk. Muhammed Emîn b. Ömer b. Abdilazîz el-Hüseynî ed-Dımaşkî İbn Âbidîn, Reddü'l-muhtâr ale'd-Dürri'l-muhtâr şerhi Tenvîri'l-ebsâr, thk. Âdil Ahmed Abdülmevcûd - Ali Muhammed Muavvız (Riyad: Dâru Âlemi'l-Kütüb, 2003), 4/455-456.

${ }^{3}$ bk. Ebû Muhammed Fahruddîn Osmân b. Alî b. Mihcen b. Yûnus es-Sûfî el-Bâriî ez-Zeylaî, Tebyîü'l-hakâik şerhu Kenzi'd-dekâik (Hâşiyetü'ş-Şelebî ile birlikte) (Bulak: el-Matbaatü'l-Kübra'l-Emîriyye, 1313), 3/26; Abdurrahmân b. Muhammed b. Süleymân Dâmad Efendi, Mecma'u'l-enhur fî șerhi Mülteka'l-ebhur (Beyrut: Dâru'l-Kütübi'l-ïlmiyye, 1998), 1/142; Abdülganî b. Tâlib b. Hammâde el-Meydânî el-Guneymî ed-Dımaşkî, el-Lübâb fî şerhi'l-Kitâb, thk. Muhammed Muhyiddîn Abdülhamîd (Beyrut: el-Mektebetü'l-ílmiyye, ts.), 3/80.

${ }^{4}$ Ebü'l-Hüseyn Ahmed b. Ebî Bekr Muhammed b. Ahmed el-Kudûrî, Muhtasarü'l-Kudûrî, thk. Kâmil Muhammed Muhammed Uveyzâ (Dârü'l-Kütübi'l-İlmiyye, 1997), 170; Mergînânî, el-Hidâye, 2/276; Zeynüddîn b. İbrâhîm b. Muhammed el-Mırrî İbn Nüceym, el-Bahrü'r-râik şerhu Kenzi'd-dekâik (Minhatü'l-hâlik ile birlikte) (Dârü'l-Kütübi'lİslâmî, ts.), 4/157.

5 İbn Âbidîn, Reddü'l-muhtâr, 5/178-179. 
halde- başka bir kadınla evlenebilir. Nitekim Sultan II. Abdülhamid vefat ettikten sonra geride kalan dokuz hanımının her birinin nikâh iddiasında bulunduğu veraset ilâmı davası, bazı hukuk tarihçileri tarafından bu minvalde yorumlanmıştır. ${ }^{6}$

Talakın gizlenmesi durumuyla ilgili gündeme gelen konulardan biri de muvâzaa ihtimalidir. Daha çok ölüm hastalığı durumunda olan bir kişinin karısını daha önce boşadığını ve iddet süresinin de tamamlandığını söylemesi halinde gündeme gelen muvâzaa ihtimali, söz konusu durumda iddetin ne zaman başlayacağı konusunda mezhep içinde ihtilafa neden olmuştur. Aşağıda araştırmanın konusu çerçevesinde muvâzaa ve kanuna karşı hile kavramları ele alındıktan sonra, meseleyle ilgili tartışmalar ve meşâyihin konuyla ilgili fetvası ayrıntılı bir şekilde incelenecektir.

\section{Muvâzaa ve Kanuna Karşı Hile Kavramları}

Genel olarak göstermelik ve danışıklı sözleşmeler için kullanılan muvâzaa kavramı, ${ }^{7}$ "gerçekleşmesini istemedikleri halde bir akdi insanların önünde gerçekleşmiş gibi göstermek üzere iki kişinin anlaşması" şeklinde tarif edilmektedir. ${ }^{8}$ Muvâzaa kavramılla önemli benzerlikleri olan kavramlardan biri de hiyeldir. Hiyel kavramının caiz olan ve olmayan şeklinde kategorize edilerek tartışıldığını ve bu bağlamda caiz olmayan hilenin günümüz hukukundaki kanuna karşs hile kavramına denk düştüğünü ifade eden Köse, ${ }^{9}$ kanuna karşı hileyi "şekil bakımından hukuka uygun

\footnotetext{
${ }^{6}$ Söz konusu veraset ilâmı davasında geride kalan dokuz hanımın her biri II. Abdülhamid'le vefatına kadar nikâhlı olduklarını ve Sultan Abdülhamid'in kendilerini boşamadığını şahitlerle ispat etmektedir. Dokuz hanımla aynı anda nikâhlı olunamayacağından hareketle Ekrem Buğra Ekinci, II. Abdülhamid'in dördüncü karısından sonraki evliliklerinde yeni bir nikâh kıyacağı zaman eşlerinden birini boşadığını ve bu şekilde vefatına kadar dörtten fazla bir evlilik yapmadığını, bununla birlikte bu boşamaları saray adabı gereği boşadığı hanımlarına bildirmediğini ifade etmektedir. Talakın tek taraflı hukukî işlemlerden biri olması sebebiyle bu durumun da İslam hukukuna aykırı olmadığını ileri sürmektedir. Ancak aşağıda ele alınacağı üzere talakın gizlenmesi durumunda iddetin ikrar anından itibaren başlayacağına ve ikrar gerçekleşmeden bu şekilde bir nikâh kıyılamayacağına dair müftâ bih görüş, bu yorumu geçersiz kılmaktadır. "Sultan II. Abdülhamid'in Eşleri ve Nikâh Meselesi” adlı makalemizde ayrıntılarıyla ele alındığını üzere burada zikri geçen nikâh, kanaatimizce nikâh-1 tenezzühî olmalıdır. bk. Ekrem Buğra Ekinci, Sultan Abdülhamid'in Son Zevcesi Behice Sultan'la Altı Ay (İstanbul: Timaş Yayınları, 2017), 169. Sultan II. Abdülhamid'in eşleri ve nikâh meselesiyle ilgili ayrıntılı bilgi için bk. Ali Akyıldız, “Son Dönem Padişahlarının Nikah Meselesi”, Osmanl İstanbulu V, ed. Feridun M. Emecen vd. (İstanbul: İstanbul 29 Mayı Üniversitesi Yayınları, 2018), 693-712; Ali Akyıldız, Saray Harem ve Mahrem (İstanbul: Timaş Yayınları, 2019), 245-262; Mustafa Ateş - Abdullah Erdem Taş, “Sultan II. Abdülhamid'in Eşleri ve Nikâh Meselesi”, Cumhuriyet İlahiyat Dergisi 24/3 (Aralık 2020), 1263-1284.

${ }^{7}$ Cengiz Kallek, “Telcie”, Türkiye Diyanet Vakfi İslam Ansiklopedisi (İstanbul: TDV Yayınları, 2011), 40/397; Saffet Köse, İslâm Hukuku Açısından Kanuna Karşı Hile ve Hile-i Şer'iyye (İstanbul: Hikmetevi Yayınları, 2020), 112.

${ }^{8}$ Muhammed Emîn b. Ömer b. Abdilazîz el-Hüseynî ed-Dımaşkî İbn Âbidîn, Nesemâtü'l-eshâr 'alâ Ifâdati'l-envâr (Pakistan: İdâratü'l-Kur'ân ve'l-‘Ulûmi'l-i̇slâmiyye, 1997), 262.

9 Saffet Köse, "Hiyel”, Türkiye Diyanet Vakfi İslam Ansiklopedisi (İstanbul: TDV Yayınları, 1998), 18/170-171; Köse, Kanuna Karşı Hile, 91.
} 
Ateş, Hanefî Mezhebine Göre Talakın Gizlenmesi Durumunda İddetin Başlangıcı: Meşâyih Fetvasının Müftâ Bih ...

bir işlem vasıta kılınarak yasaklanmış bir neticeyi elde etme kastıyla yapılan muamele" olarak tanımlamaktadır. ${ }^{10}$ Buna göre kanuna karşı hilede yapılan işlemin şekil bakımından hukuka uygun olması, kanun koyucunun maksadına aykırılık ve hile kastı olmak üzere üç unsur bulunmaktadır. ${ }^{11}$

Muvâzaa ve kanuna karşı hilenin en önemli ortak noktası, ilgili hükmün amacı dışında başka bir gayeyi gerçekleştirmeye yönelik olmalarıdır. Bununla birlikte aralarında bazı farklılıklar da mevcuttur. Söz gelimi muvâzaada taraflar gerçek amaçlarını gizlediği halde, kanuna karşı hilede gizlilik söz konusu değildir. Yine muvâzaada, göstermelik olarak yapılan akdin üçüncü tarafları aldatma maksadı bulunmasına rağmen, kanuna karşı hilede kanunen caiz olan işlemler vasıtasıyla kanunun maksadına aykırı sonuçlara ulaşmak amaçlanmaktadır. ${ }^{12}$

Araştırma konumuz olan talakın gizlenmesi durumunda iddetin başlangıcı meselesini hem muvâzaa hem de kanuna karşı hile açısından incelemek mümkündür. Muvâzaa açısından bakıldığında, belirli bir maksadı gerçekleştirmek için karısıyla anlaşan koca, söz gelimi beş yıl önce karısını boşadığını söyleyebilir. Bu örnek üzerinden düşünüldüğünde -iddetin, talakın akabinde başladığı kabul edilirse- karı ve kocanın muvâzaa yapmak suretiyle gerçekleştirmek isteyebilecekleri maksatlara şu örnekler verilebilir:

Böyle bir durumda kadının iddeti tamamlanmış olacağından kadın iddet beklemekten, erkek de nafaka ve süknâ gibi birtakım yükümlülüklerden kurtulmuş olur. Burada muvâzaa yapmalarına sebep olabilecek şekilde her iki tarafın da çıarı bulunmaktadır. Yine hasta olan bir kimse, karısına mirastan düşecek paydan daha fazla bir mal bırakmak istediğinde karısıyla yukarıdaki örnekteki gibi bir muvâzaa yapabilir. Bu durumda karısı onun için yabancı biri konumunda olacağından, karısının mirastaki payından daha fazla bir miktarı vasiyet edebilir veya ona borcu olduğunu beyan edebilir. Böylelikle karı ve koca aralarında daha önce anlaştıkları bir amaca (yani kadının terekeden daha fazla mal alması amacına) ulaşmış olurlar. Bir diğer muvâzaa ihtimali de yukarıda da değinildiği üzere erkeğin boşadığı karısının kız kardeşiyle ya da boşadı̆̆ karısı dışında dört kadınla nikâhı meselesinde gündeme gelmektedir. Normal şartlarda boşadığı karısının kız kardeşine ya da onun dışında dördüncü kadına nikâh kıymak istediğinde, boşadığı karısının iddetini beklemek zorundadır. Bu iddet süresini beklemeksizin nikâh kıymak istediğinde, karısını söz gelimi bir yıl önce boşadığını ve bu durumda iddetinin dolduğunu iddia edebilir. Burada boşadığı karısının da iddet bekleme yükümlülüğü ortadan kalkacağı için karı-kocanın muvâzaa yapmış olma töhmeti söz konusudur.

$\mathrm{Bu}$ konu çerçevesinde değerlendirilebilecek örneklerden biri de dört karısı olduğu halde başka bir kadınla evlenmek isteyen bir kimsenin, mevcut hanımlarından herhangi birini onlara

10 Köse, "Hiyel”, 18/171.

11 Köse, “Hiyel”, 18/171; Köse, Kanuna Karşı Hile, 94.

12 Köse, Kanuna Karşı Hile, 114-115. 
haber vermeden boşayıp iddet süresi de dolduğunda beşinci kadına nikâh kıymasıdır. Böyle bir durumda ilk dört kadın da mevcut konumlarından ve kocalarının mirasından mahrum olmamak için söz konusu talakın kimin hakkında olduğunu sorgulamayabilirler. Böylelikle koca, aynı anda beş ya da daha fazla kadınla nikâhlı görünebilir ya da vefat ettiğinde hangi karısını boşadığı bilinmediği için beş kadının her biri aynı kocanın vârisi olabilir. Bu örnek muvâzaadan daha çok, günümüzde kanuna karşı hile olarak ifade edilen kavrama uygun düşmektedir. Zira burada koca ile kadının gizli bir anlaşma yapmaları şart değildir. Bununla birlikte, bu örnekte -meşâyihin fetvası göz ardı edilirse- işlemin kanuna uygunluğu, Şâri'in maksadına aykırılık ve hile kastı gibi kanuna karşı hile kavramının bütün özellikleri bulunmaktadır.

\section{Talakın Gizlenmesi Durumunda İddetin Başlangıcı}

\subsection{Meşâyihin Fetvasından Önceki Durum}

Bir kimsenin, karısını daha önce boşadığını ikrar etmesi durumunda karısı açısından söz konusu ikrarı "tasdik" veya "yalanlama" ya da "bu talaktan haberinin olmadığını açıklaması" şeklinde üç farklı durum gündeme gelmektedir. Bu sebeple konu, kadının tasdik etmesi ve yalanlaması/bilmiyorum demesi ihtimallerine binaen iki açıdan değerlendirilmektedir.

Muhammed b. Hasan eş-Şeybânînin (ö. 189/805) el-Asl adlı eserinde konuya dair şöyle bir mesele zikredilmektedir: Bir adamın hastalık esnasında karısına "sağlığımda seni üç talakla boşamıştım ve iddetin tamamlanmıştı" demesi durumunda kadın da bu konuda adamı tasdik ederse kadın artık ona vâris olmaz. Yine adam daha önce boşadığını söylediği bu kadına borcu olduğunu ikrar etse ya da vasiyette bulunsa caizdir. Kadın artık başka bir kimseyle evlenebilir, adam da bu kadının kız kardeşi ve bununla birlikte üç kadınla daha evlenebilir. Bu görüş İmâmeyn'e aittir. Ebû Hanîfe'ye (ö. 150/767) göre ise bu kadın miras ile borçtan/vasiyetten hangisi daha az ise onu alır. ${ }^{13}$

Bu meseleyi el-Mebsût'ta ayrıntılı bir şekilde inceleyen Serahsî (ö. 483/1090 [?]), İmâmeyn ile Ebû Hanîfe'nin görüşlerinin dayanaklarını ortaya koymaktadır. Buna göre, kocasının kendisini daha önce boşadığına ve iddetinin dolduğuna dair söylemini kadının doğrulaması durumunda, söz konusu talak karı-kocanın hakları konusunda beyyine ile sabit olmuş gibidir. Çünkü kadının mirasta hakkı vardır ve kadın bu ikrarıyla miras hakkını düşürmektedir. Serahsî’nin ifadesiyle İmâmeyn'e göre, kadın artık adama mirasçı olamayacak şekilde bir yabancı konumundadır. Bu sebeple adamın kadına vasiyeti ya da borcu olduğuna dair ikrarı geçerli olur ve yine kadın beklemeksizin başka biriyle evlenebilir. Şayet burada muvâzaa töhmeti dikkate alınacak olsa, evlilik hususunda da bu töhmete itibar edilmesi gerekir. Oysa adamın boşadığı karısının kız

13 Ebû Abdillâh Muhammed b. el-Hasen b. Ferkad eş-Şeybânî, el-Asl, thk. Muhammed Boynukalın (Beyrut: Dâru İbn Hazm, 2012), 4/539. 
Ateş, Hanefî Mezhebine Göre Talakın Gizlenmesi Durumunda İddetin Başlangıcı: Meşâyih Fetvasının Müftâ Bih ...

kardeşiyle veya onun dışında başka dört kadınla evliliği ve kadının beklemeksizin başka biriyle evlenmesi caizdir. Bu durumda söz konusu meselede muvâzaa töhmetinin olmadığı anlaşılır. Serahsî Ebû Hanîfe'nin görüşünü de şu şekilde temellendirmektedir: Bu adamın zâhiren karısıyla hala nikâhlıyken hastalanması, borç ikrarını ve vasiyeti engelleyen bir durum olduğu için muvâzaa yapma ihtimalleri ortaya çıar. Buradaki muvâzaa töhmeti kadına kalacak mirasla ilgili değildir, aksine bu mirasın miktarı üzerindeki ziyade hakkındadır. Bu sebeple töhmetin söz konusu olduğu miras üzerine ziyade meselesinde vasiyet/borç ikrarı ile mirastan hangisi azsa kadına o verilir. Diğer taraftan bu töhmet, karı-koca ve diğer vârislerle ilgili olduğu için kul hakkıyla alakalıdır. Allah hakkı kapsamında herhangi bir töhmet olmadığından dolayı kadının başka biriyle, adamın da dört kadınla ya da boşadığı kadının kız kardeşiyle evlenmesi caizdir. ${ }^{14}$ Bu meselede İmâmeyn ile Ebû Hanîfe arasında her ne kadar ihtilaf olsa da her iki tarafın da iddeti talaktan itibaren başlattığı görülmektedir. Zira kadının talak ikrarını tasdik etmesi, haklarından mahrum edilme ihtimalini ortadan kaldırmaktadır. Ebû Hanîfe'nin vasiyet/borç ikrarı konusunda muvâzaa ihtimalini dikkate almasından hareketle, diğer durumlarda muvâzaa ihtimali görmediği söylenebilir.

Bir kimsenin, karısını daha önce boşadığını ikrar etmesi durumunda karısının bu ikrarı yalanlaması ya da bu talaktan haberi olmadığını söylemesi, tasdik etmesi durumundaki meseleden ayrı değerlendirilir. Çünkü ikrar, kadının nafaka ve süknâ hakkını düşürmektedir. Bu sebeple mezhep imamlarına göre kadının nafaka ve süknâ hakkını korumak için adamın daha önce karısını boşadığını ikrar etmesi durumunda iddet, ikrar anından itibaren başlar ve böylelikle iddet süresi içerisinde kadın nafaka ve süknâ hakkını kullanma imkânı bulur. ${ }^{15}$ Bu mesele, kadının nafaka ve süknâ hakkıyla ilgili görüldüğü için, bazı kaynaklarda meşâyihe göre talakın ikrar vaktinden itibaren başlaması sadece nafaka ve süknâ hakkına hasredilmiş, boşanan kadının kız kardeşiyle ya da onun dışında dört kadınla evlenme meselesinde iddetin talak vaktinden itibaren dikkate alınacağı ifade edilmiştir. ${ }^{16}$ Ancak Hâherzâde'ye (ö. 483/1090) göre evlilik hususunda da talakın ikrar vaktinden itibaren başlaması gerekir. ${ }^{17}$

\subsection{Meşâyih Fetvasının Müftâ Bih Hale Geliş Süreci}

14 Ebû Bekr Muhammed b. Ebî Sehl Ahmed es-Serahsî, Kitâbü'l-Mebsût (Beyrut: Dârü'l-Marife, ts.), 6/165.

15 Serahsî, el-Mebsût, 18/145. Burhânüddîn (Burhânü'ş-Şerîa) Mahmûd b. Ahmed b. Abdilazîz el-Buhârî elMergînânî, el-Muhîtu'l-Burhânî, thk. Nuaym Eşref Nûr Ahmed (Riyâd: Mektebetü'r-Rüşd, 2004), 5/231; Mevsılî, elİhtiyâr, 3/174; Zeylaî, Tebyînül-hakâik, 3/32; Kemâlüddîn Muhammed b. Abdilvâhid b. Abdilhamîd es-Sivâsî elİskenderî İbnü'l-Hümâm, Fethu'l-kadîr (Dârü'l-Fikr, ts.), 4/329; el-Fetâva'l-Hindiyye (Bulak: Matbaatü'l-Kübra'lEmîriyye, 1310), 1/532.

16 bk. Burhâneddin el-Buhârî, el-Muhîtu'l-Burhânî, 5/231; Muhammad Akram Hakim, Cemâleddin el-Konevînin (V. 770/1369) el-Gunye fi'l-Fetâvâ Adlı Eserinin Tahkik ve Değerlendirilmesi (Konya: Necmettin Erbakan Üniversitesi, Sosyal Bilimler Enstitüsü, Doktora Tezi, 2016), 255.

17 bk. Hakim, Konevînnin el-Gunye fi'l-Fetâvâ Adlı Eserinin Tahkik ve Değerlendirilmesi, 255. 
Meşâyihin konuyla ilgili fetvasına geçmeden önce Hanefî mezhebinde sıkça karşılaşılan meşâyih kavramı üzerinde kısaca durmak yerinde olacaktır. Meşâyih, son dönem bazı Hanefî kaynaklarında "Ebû Hanîfe'ye yetişemeyen fakihler" şeklinde tanımlanmaktadır. ${ }^{18}$ Ancak meşâyih döneminin başlangıcına işaret eden bu tanım dışında söz konusu kavram hakkında klasik kaynaklarda pek bir bilgiye rastlanmaz. Ali Bardakoğlu meşâyihi, "genelde bir bölgede belirli bir fakihin etrafında toplanan veya benzer fikhî tercihlere sahip bulunan fakihler grubu" şeklinde tarif etmekte, ${ }^{19}$ Eyüp Said Kaya ise meşâyihin “... iftâ ve kaza faaliyetlerinde esas olacak hükümlerin tespitinde ortak kabul ve kıstaslara sahip olan fakihlerden müteşekkil” olduğunu ifade etmektedir. ${ }^{20}$ Meşâyih döneminin başlangıcı ve bitişine dair çeşitli görüşler ileri sürülmekle birlikte, ${ }^{21}$ Osman Bayder'in tespitine göre hicrî 200 yılından itibaren muhtelif Hanefî fakihler için hemen hemen her dönemde meşâyih ifadesi kullanılmıştır. ${ }^{22}$ Bu çalışmada ise genel olarak meşâyih kavramıyla; Ebû Hanîfe'nin öğrencilerinden sonra gelen ve Irak, Belh, Buhara, Semerkand gibi bölge isimleriyle birlikte anılan mütekaddimûn dönem Hanefî fakihleri kastedilmektedir.

Talakın gizlenmesi durumunda iddetin başlangıcı meselesi, yukarıda ele alındığı üzere meşâyihin fetvasından önce kadının talakı tasdik etmesi veya yalanlaması/haberinin olmadığını beyan etmesi şeklinde iki farklı açıdan değerlendirilmiştir. Her iki durumda da belirleyici olan husus, kadının nafaka ve süknâ hakkıdır. Kadın, daha önce yapılmış olduğu iddia edilen talakı tasdik ettiğinde kendi rızasıyla nafaka ve süknâ hakkı ile miras hakkını düşürmüş olur. Diğer taraftan kadının yalanlaması/haberinin olmadığını söylemesi durumunda, kadının rızası olmaksızın haklarının düşmesi söz konusu olacağından kocanın önceki bir zamana talakı isnad etmesi kabul edilmez ve kadının haklarını korumak amacıyla iddet, ikrar vaktinden itibaren başlatılır.

Konuyla ilgili meşâyihin fetvasına göre ise, talakın gizlenmesi durumunda -kadın ister tasdik etsin ister yalanlasın veya haberi olmadığını beyan etsin- iddet, talakın ikrarından itibaren başlar. İddetin ikrardan itibaren başladığına yönelik fetva, Ebü'l-Leys es-Semerkandînin (ö. 373/983)

18 İbn Âbidîn, Reddü'l-muhtâr, 6/735.

19 Ali Bardakoğlu, "Hanefi Mezhebi”, Türkiye Diyanet Vakfi İslâm Ansiklopedisi (İstanbul: TDV Yayınları, 1997), 16/9.

20 Eyyüp Said Kaya, Mezheblerin Teşekkülünden Sonra Fıkhî İstidlal (İstanbul: Marmara Üniversitesi Sosyal Bilimler Enstitüsü, Doktora, 2001), 179.

${ }^{21}$ bk. Seyit Mehmet Uğur, "Hanefî Mezhebinde Müftâ Bih Görüşün Belirlenmesinde Meşâyihın Rolü”, 6. Türkiye Lisansüstü Çalışmaları Kongresi-Bildiriler Kitabı III (İstanbul: İlem, 2017), 100-101.

22 Osman Bayder, Kurucu İmama Muhalefetin İmkan ve Sinırı -Hanefi Mezhebi Örneği- (Ankara: Maarif Mektepleri Yayınları, 2018), 117-119. Meşâyih hakkında ayrıntılı bilgi için bk. Kaya, Mezheblerin Teşekkülünden Sonra Fikhî İstidlal, 179, 209-222,170-277 vd; Bayder, Kurucu İmama Muhalefetin İmkan ve Sintr, 117-125; Uğur, "Hanefî Mezhebinde Müftâ Bih Görüşün Belirlenmesinde Meșâyihın Rolü”, 99-112; Seyit Mehmet Uğur, Hanefilerde Mezhep İçi Tercih ve Usulü (İstanbul: M.Ü. İlahiyat Fakültesi Vakfi Yayınları, 2019), 104-115. 
Ateş, Hanefî Mezhebine Göre Talakın Gizlenmesi Durumunda İddetin Başlangıcı: Meşâyih Fetvasının Müftâ Bih ...

Nevâzil adlı eserinde Ebû Bekir Muhammed b. Ahmed el-İskâf el-Belhîye (ö. 336/947) ${ }^{23}$ nispet edilerek zikredilmektedir. ${ }^{24}$ Ebû Bekir el-İskâf'ın fetvasına göre bir adam karısını elli yıl önce boşadığını ikrar etse iddet, ikrar vaktinden itibaren başlar. Bununla birlikte kadının nafaka ve süknâ hakkı İskâfın bu fetvasında da gündeme gelmektedir. Her ne kadar iddet ikrar vaktinden itibaren başlayacak olsa da kadın kocasının ikrarını tasdik ederse nafaka ve süknâ hakkı düşer, ancak talaktan ikrar vaktine kadar geçen sürede duhul gerçekleşmişse ikinci mehre hak kazanır. Diğer taraftan kadın eğer kocasını yalanlarsa, bu durumda tek mehir alır ve nafaka ile süknâ hakkı olur. ${ }^{25}$ Ebû Bekir el-İskâf' in bu fetvası, aynı ibarelerle Ahmed b. Musa el-Keşŝînin (ö. 550/1155) Mecmu'u'l-havâdis ve'n-nevâzil ve'l-vâkı ât adlı eserinde tekrarlanmaktadır. ${ }^{26}$

Ebû Bekir el-İskâf'ın fetvası her ne kadar hicrî üçüncü asrın sonu ile dördüncü asrın başına denk düşse de bu yöndeki bir fetvanın meşâyihe nispetle varlığına dair ilk beyana Burhâneddin elMergînânînin (ö. 593/1197) Hidâye adlı eserinde rastlanılmaktadır. Mergînânî, iddetin talakın ve vefatın akabinde başlayacağını belirttikten sonra, meşayihin muvâzaa töhmetini ortadan kaldırmak için talakta iddetin ikrar vaktinden itibaren başlayacağı yönünde fetva verdiklerini ifade ederek kendisi de zımnen bu görüşü tercih etmektedir. ${ }^{27}$ Hidâye'deki bu fetvanın ilk kaynağının Ebû Bekir el-İskâf olduğunu söylemek güç olsa da en azından bu fetvanın kaynaklarından birinin Ebû Bekir el-İskâf olduğu açıktır. Mergînânînnin "Meşâyihimiz böyle fetva verdiler" şeklindeki çoğul ifadesi, farklı fakihlerin benzer fetvaları olabileceğine işaret etmekle birlikte, el-İskâf'ın fetvası sonraki dönemde kabul görerek diğer fakihler tarafından da benimsenmiş olabilir. Nihayetinde söz konusu ifade, bu fetvanın kolektif bir tercih olduğunu göstermektedir.

Talakın gizlenmesi durumunda iddetin ikrar vaktinden itibaren başlayacağına dair fetvanın meşâyihe nispetle ilk zikredildiği kaynaklardan biri de Mergînânînin çağdaşlarından olan

23 Hayatı hakkında bilgi için bk. Ebû Muhammed Muhyiddîn Abdülkâdir b. Muhammed el-Kureşî, el-Cevâhiru'lmudiyye fi tabakâti'l-Hanefiyye, thk. Abdülfettâh Muhammed el-Hulv (Cîze: Hicr li't-Tıbâ‘a ve'n-Neşr, 1993), 3/76, 4/15-16; Mahmûd b. Süleymân el-Hanefî el-Kefevî, Ketâibü a'lâmi'l-ahyâr min fukahâi mezhebi'n-Nu'mâni'l-muhtâr, thk. Saffet Köse vd. (İstanbul: Mektebetü'l-İrşâd, 2017), 2/30-32.

24 Fetvayla ilgili kısım, "Ebû Bekir'e soruldu” ifadesiyle başlamaktadır. Ebü’l-Leys es-Semerkandî, kitabının başında dokuz Hanefî fakihinin ismini zikrederek bu fakihlerin nevâzil türü meselelerde yaptıkları ictihadlarını derlediğini beyan etmektedir. Burada ismi zikredilen fakihlerden biri de Ebû Bekir Muhammed b. Ahmed elİskâf'tır. Dolayısıyla kitap içerisinde geçen Ebû Bekir künyesiyle, Ebû Bekir Muhammed b. Ahmed el-İskâf kastedilmektedir. bk. Ebü'l-Leys Nasr b. Muhammed b. Ahmed b. İbrâhîm es-Semerkandî, Kitâbü'n-Nevâzil (İstanbul: Süleymaniye Kütüphanesi, Fatih, 2414), 1 b.

25 Ebü'l-Leys es-Semerkandî, Kitâbü’n-Nevâzil, 82b-83a.

${ }^{26}$ bk. Abdumalik Tuychibaev, Ahmed b. Musa el-Keşşînin Mecmu'u'l-hevâdis ve'n-nevâzil ve'l-vâkı ât Adlı Eserinin Tahkik ve Değerlendirilmesi (Ankara: Ankara Üniversitesi, Sosyal Bilimler Enstitüsü, Doktora Tezi, 2021), 212.

27 Mergînânî, el-Hidâye, 2/276. Ayrıca bk. Ahmed Salih Ahmed Gyunesh, Burhaneddin el-Mergînânînin "Muhtâratu'nnevâzil” Eserinin Edisyon Kritiği (Konya: Selçuk Üniversitesi Sosyal Bilimler Enstitüsü, Yüksek Lisans, 2010), 218. 
Burhâneddin el-Buhârînnin (ö. 616/1219) el-Muhîtu'l-Burhânî adlı eseridir. Meseleyi oldukça tafsilatlı bir şekilde inceleyen Burhâneddin el-Buhârî, kadının ikrarı yalanlaması ve tasdik etmesi durumlarını ayrı ayrı değerlendirmektedir. Meşâyihin fetvasını da kadının ikrarı tasdik ettiği durumda zikretmektedir. Zira yukarıda da değinildiği üzere kadının ikrarı yalanlaması durumunda zaten iddet ikrar vaktinden itibaren başlamaktadır. Muhît'te dikkat çeken hususlardan biri de meselenin "elli yıl önce karısını boşadığını ikrar eden adam” örneği üzerinden sunulmasıdır. ${ }^{28}$ Ebû Bekir el-İskâfın fetvasının da aynı örneği içerdiği dikkate alındığında, söz konusu fetvanın benimsenmesinde Ebû Bekir el-İskâf ın etkisinin büyük olduğu söylenebilir. Öte yandan Burhâneddin el-Buhârî, fetvayı Belh meşâyihine nispetle zikretmektedir. Ebû Bekir el-İskâf'ın da Belhli olduğunu burada tekrar hatırlatmak gerekir.

Mergînânînnin bir diğer çağdaşı olan Kâdîhân (ö. 592/1196), meşhur eseri el-Fetâva’lHâniyye'de el-Muhîtu'l-Burhânî'dekine benzer şekilde meseleyi kadının ikrarı yalanlaması ve tasdik etmesi durumuna göre ayrı ayrı ele almaktadır. Buna göre bir adam karısını beş sene önce boşadığını ikrar etse, kadın da bu isnadı yalanlasa ya da talaktan haberi olmadığını söylese, iddet ikrardan itibaren başlar ve kadının nafaka ile süknâ hakkı vardır. Eğer kadın adamın ikrarını tasdik ederse, Şeybânînin el-Asl adlı eserinde zikredilene göre iddet talak vaktinden itibaren başlar. Ancak müftâ bih görüşe göre iddet ikrar vaktinden itibaren başlar. Kadının bu ikrarı tasdik etmesi, sadece nafaka hakkını düşüren bir etkendir. ${ }^{29}$ el-Fetâva'l-Hâniyye'de meseleyle ilgili dikkat çeken husus, mezkûr fetvanın meşâyihe nispet edilmeden zikredilmesidir. Bununla birlikte Kâdîhân, "elfetvâ aleyhâ" ifadesiyle söz konusu görüşün müftâ bih olduğunu açıkça vurgulayan ilk müelliflerden biridir.

Mergînânî, Burhâneddin el-Buhârî ve Kâdîhân'ın yaşadıkları tarih dikkate alındığında, mezkûr fetvanın hicrî altıncı asıra kadar Hanefî mezhebinde istikrar kazanarak müftâ bih hale geldiği söylenebilir. Diğer taraftan yine Maveraünnehir ulemasından olan Serahsînnin meşhur eseri el-Mebsût'ta söz konusu fetvanın herhangi bir şekilde yer almamış olması, hicrî beşinci asırda bu fetvanın henüz çok fazla gündemde olmadığına işaret etmektedir. Bununla birlikte yine hicrî beşinci asır Hanefî fakihlerinden olan Ebü'l-Hasan Ali b. Hüseyin es-Suğdî (ö. 461/1068), el-Asl'da geçen zâhirü'r-rivâye görüş ile mezkûr fetvayı telif etme çabasındadır. Suğdî̀ye göre el-Asl'da yer alan iddetin talak vaktinden itibaren başlayacağına dair görüş, talakın yapıldığı söylenen tarihten itibaren karı-kocanın ayrı yaşıyor olma durumuna hamledilir. Ancak karı-koca birlikte yaşamaya

28 bk. Burhâneddin el-Buhârî, el-Muhîtu'l-Burhânî, 5/231.

29 Ebü'l-Mehâsin Fahrüddîn Hasen b. Mansûr b. Mahmûd el-Özkendî el-Fergânî Kâdîhân, el-Fetâva'l-Hâniyye (elFetâva'l-Hindiyye ile birlikte) (Bulak: Matbaatü'l-Kübra'l-Emîriyye, 1310), 1/552. 
Ateş, Hanefî Mezhebine Göre Talakın Gizlenmesi Durumunda İddetin Başlangıcı: Meşâyih Fetvasının Müftâ Bih ...

devam etmişse, her ikisinin de yalan söylediği anlaşılır ve söz konusu ikrar ile kadının tasdiki dikkate alınmaz. ${ }^{30}$

Hicrî altıncı asırdan itibaren Hanefî kaynaklarda yukarıda ayrıntılarına yer verilen tüm bu birikim çeşitli boyutlarıyla yer almakta ve meşâyihin fetvasının müftâ bih görüş olduğu vurgulanmaktadır. ${ }^{31}$ Meşâyih fetvasına yer verilen kaynaklarda sıklıkla Hidâye'ye atıf yapılması, hicrî altıncı asır sonrasında söz konusu fetvanın müftâ bih olarak benimsenmesinde Mergînânînin etkili olduğuna işaret etmektedir. ${ }^{32}$ Bununla birlikte Sadrüşşehîd'in (ö. 536/1141) el-Fetâva'ssuğrâ'sı, Burhaneddin el-Buhârî'nin Tetimmetü'l-fetâvâ ile Zahiretü'l-fetâvâ'sı ve Kâdîhân'ın elFetâva'l-Hâniyye'si de Hidâye sonrası eserlerde söz konusu fetvânın kaynağı olarak kullanılmaktadır. ${ }^{33}$ Yine mezkûr fetvayla ilgili dikkat çeken hususlardan biri de Hidâye şerhlerinde ve bu şerhlerden alıntı yapan eserlerde fetvanın Buhara ve Semerkand meşayihine ait olduğunun ifade edilmesidir. ${ }^{34}$ Oysa el-Muhîtu'l-Burhânî ve el-Gunye fi'l-fetâvâ gibi eserlerde bu fetvanın Belh meşâyihine ait olduğu belirtilmektedir..$^{35}$ Mezkûr fetvânın en erken Ebû Bekir el-İskâf el-Belhî̀ye nispet edilmesi de Belh meşâyihine aidiyetini kuvvetlendirmektedir. Bununla birlikte aynı fetva, Buhara ve Semerkand meşâyihi tarafından da benimsenmiş olabilir. Ancak bu konuda herhangi bir bilgiye erişilememiştir.

\section{Sonuç}

30 bk. Burhâneddin el-Buhârî, el-Muhîtu'l-Burhânî, 5/231; Zeylaî, Tebyînül-hakâik, 3/32; ̇̇bnü'l-Hümâm, Fethu'l-kadîr, 4/329; İbn Âbidîn, Reddü'l-muhtâr, 5/203; Meydânî, el-Lübâb, 3/84.

31 bk. Mevsılî, el-İhtiyâr, 3/174-175; Zeylâ̂, Tebyînül-hakâik, 3/32; Ekmelüddîn Muhammed b. Mahmûd b. Ahmed el-Bâbertî er-Rûmî el-Misrî, el-İnâye şerhu'l-Hidâye (Dârü'l-Fikr, ts.), 4/329; Radıyyüddîn Ebû Bekr b. Alî b. Muhammed el-Haddâd, el-Cevheretü'n-neyyire 'alâ Muhtasari'l-Kudûrî (el-Matbaatü'l-Hayriyye, 1322), 2/78; Ebû Muhammed (Ebü's-Senâ) Bedrüddîn Mahmûd b. Ahmed b. Mûsâ b. Ahmed el-Aynî, el-Binâye şerhu'l-Hidâye (Beyrut: Dârü'l-Kütübi'l-İlmiyye, 2000), 5/610; İbnü'l-Hümâm, Fethu'l-kadîr, 4/329; İbn Nüceym, el-Bahrü'r-râik, 4/157; Ebü'l-İhlâs Hasen b. Ammâr b. Alî eş-Şürünbülâlî el-Vefâi el-Misrî, Gunyetü zevi'l-ahkâm fì buğyeti'd-Düreri'lahkâm (Karaçi: Mir Muhammed Kütüphane, ts.), 1/403; Dâmad Efendi, Mecmeu'l-enhur, 2/149; el-Fetâva'l-Hindiyye, 1/532; İbn Âbidîn, Reddü'l-muhtâr, 5/203-205; Meydânî, el-Lübâb, 3/84.

32 bk. Haddâd, el-Cevheretü'n-neyyire, 2/78; İbn Nüceym, el-Bahrü'r-râik, 4/157; Şihâbüddin Ahmed b. Muhammed b. Ahmed eş-Şelebî, Hâşiyetü’ş-Şelebî alâ Tebyîni'l-hakâik (Bulak: el-Matbaatü'l-Kübra'l-Emîriyye, 1313), 3/32; İbn Âbidîn, Reddü'l-muhtâr, 5/16; Meydânî, el-Lübâb, 3/84.

33 bk. Bâbertî, el-İnâye, 4/329; Aynî, el-Binâye, 5/610; İbn Nüceym, el-Bahrü'r-râik, 4/157; Şelebî, Hâşiyetü’ş-Şeleb̂̂, 3/32; el-Fetâva'l-Hindiyye, 1/532.

34 bk. Bâbertî, el-ínâye, 4/329; Aynî, el-Binâye, 5/610; İbn Nüceym, el-Bahrü'r-râik, 4/157. İbnü'l-Hümâm Mergînânînin burada Buhara ve Semerkand meşâyihini kastettiğini ifade ettikten sonra söz konusu fetvanın Belh meşâyihine nispet edilmesini eleştirmektedir. bk. İbnü'l-Hümâm, Fethu'l-kadîr, 4/329.

35 bk. Burhâneddin el-Buhârî, el-Muhîtu'l-Burhânî, 5/231; Hakim, Konevînin el-Gunye fi'l-Fetâvâ Adlı Eserinin Tahkik ve Değerlendirilmesi, 255. 
Hanefî mezhebine göre iddet, kural olarak boşanma durumunda talakın akabinde, ölüm durumunda ise vefatla birlikte başlar. Ancak bir kimsenin, karısını daha önce boşadığını ikrar etmesi ve karısının bu ikrarı yalanlaması ya da bu talaktan haberi olmadığını söylemesi durumunda iddet, kadının nafaka ve süknâ hakkını korumak amacıyla ikrar anından itibaren başlatılır. Öte yandan kadının bu ikrarı tasdik etmesi durumunda nafaka ve süknâ hakkını koruma durumu ortadan kalktığı için iddetin yine kural olarak talakın akabinde başlaması gerekir. Ancak meşâyih, muvâzaa töhmeti sebebiyle ve talakın gizlenmesini yasaklamak amaciyla bu tür durumlarda kadın ikrarı tasdik etse bile iddetin ikrar anından itibaren başlayacağı yönünde bir fetva vermiş ve bu fetva mezhepte müftâ bih hale gelmiştir.

Meşâyihin fetvasındaki muvâzaa gerekçesi, benzer bir meselede Ebû Hanîfe tarafından da kullanılmıştır. Bir adamın hastalık esnasında karısına "sağlı̆̆ımda seni üç talakla boşamıştım ve iddetin tamamlanmıştı" demesi durumunda kadın da bu konuda adamı tasdik ederse Ebû Hanîfe'ye göre kadın, miras ile borçtan/vasiyetten hangisi daha az ise onu alır. Çünkü adamın karısıyla zâhire göre nikâhlıyken hastalanması, borç ikrarını ve vasiyeti engelleyen bir durumdur ve bu konuda muvâzaa yapma ihtimalleri gündeme gelir. Bu sebeple vasiyet/borç ikrarı ile mirastan hangisi azsa kadına o verilir. Meşâyihin talakın gizlenmesi durumunda iddetin başlangıcı hakkındaki fetvası da muvâzaa töhmetini kaldırmak ya da kanuna karşı hileyi önlemek amacına matuf olduğuna göre, söz konusu fetvanın Ebû Hanîfe'nin zikri geçen görüşünden hareketle ortaya konduğu söylenebilir. Başka bir açıdan bakıldığında meşâyihin mezkûr fetvasının zâhirü'rrivâyeye açıkça aykırı olmasına rağmen mezhepte müftâ bih olarak kabul görmesi, mezhep imamı Ebû Hanîfe'nin benzer meseledeki tavrına dayanmaktadır. Nitekim zaman zaman karşılaşılan "Ebû Hanîfe yaşasaydı o da böyle hüküm verirdi" şeklindeki ifadeler de bu tür aykırı fetvaları temellendirmek amacıyla söylenmektedir.

Talakın gizlenmesi durumunda iddetin ikrar vaktinden itibaren başlayacağına dair fetvanın en geç hicrî altıncı asırdan itibaren mezhepte müftâ bih hale geldiği anlaşılmaktadır. Bu yüzyıldan itibaren konuyla ilgili farklı bir görüşe ya da herhangi bir itiraza rastlanılmamıştır. Fetvanın mezhepte müftâ bih olarak benimsenmesinde özellikle Mergînânî, Kâdîhân ve Burhâneddin elBuhârînnin etkili olduğu görülmektedir. Diğer taraftan Ebü'l-Hasan es-Suğdî’nin zâhirü'r-rivâye görüşü hakkında yaptığı açıklama, mezkûr fetvanın esasında zâhirü’r-rivâyeye aykırı olmadığını göstermesi bakımından önemli görülmüş ve birçok kaynakta bu vesileyle zikredilmiştir. Suğdî̀ye göre el-Asl'da yer alan iddetin talak vaktinden itibaren başlayacağına dair görüş, talakın yapıldığı söylenen tarihten itibaren karı-kocanın ayrı yaşıyor olma durumuna hamledilir. Nitekim karıkocanın ayrı yaşaması, talaka delalet eder ve muvâzaa ihtimali ortadan kalkar. Ancak karı-koca birlikte yaşamaya devam etmişse, bu durumda her ikisinin de yalan söylediği anlaş1lır ve söz konusu ikrar ile kadının tasdiki dikkate alınmaz. 
Ateş, Hanefî Mezhebine Göre Talakın Gizlenmesi Durumunda İddetin Başlangıcı: Meşâyih Fetvasının Müftâ Bih ...

Yapılan araştırmada en geç hicrî altıncı asırda müftâ bih hale geldiği anlaşılan ve meşâyihe nispetle aktarılan bu fetvanın, ulaşılabilen kaynaklar çerçevesinde ilk olarak Ebû Bekir el-İskâf elBelhî̀ye nispet edildiği görülmüştür. Sonraki dönemlerde de mezkûr fetvanın Belh meşâyihine nispetle zikredilmesi, fetvanın benimsenmesinde Ebû Bekir el-İskâf in etkisinin büyük olduğuna işaret etmektedir. Bununla birlikte aynı fetvanın farklı zamanlarda diğer bölgelerin fakihleri tarafından da gündeme getirilmiş olması elbette muhtemeldir. Öte yandan Ebû Bekir el-İskâf'in hicrî dördüncü asırda yaşadığı dikkate alındığında, fetvanın en az iki asır sonra müftâ bih hale geldiği söylenebilir.

\section{Kaynakça}

Acar, Halil İbrahim. “Talak”. Türkiye Diyanet Vakfi İslâm Ansiklopedisi. 39/496-500. İstanbul: TDV Yayınları, 2010.

Akyıldız, Ali. Saray Harem ve Mahrem. İstanbul: Timaş Yayınları, 2019.

Akyıldız, Ali. "Son Dönem Padişahlarının Nikah Meselesi”. Osmanlı İstanbulu V. ed. Feridun M. Emecen vd. 693-712. İstanbul: İstanbul 29 Mayıs Üniversitesi Yayınları, 2018.

Ateş, Mustafa - Taş, Abdullah Erdem. "Sultan II. Abdülhamid'in Eşleri ve Nikâh Meselesi”. Cumhuriyet İlahiyat Dergisi 24/3 (Aralık 2020), 1263-1284.

Aynî, Ebû Muhammed (Ebü’s-Senâ) Bedrüddîn Mahmûd b. Ahmed b. Mûsâ b. Ahmed el-Aynî. elBinâye şerhu'l-Hidâye. 1-13 Cilt. Beyrut: Dârü'l-Kütübi'l-ìlmiyye, 2000.

Bâbertî, Ekmelüddîn Muhammed b. Mahmûd b. Ahmed el-Bâbertî er-Rûmî el-Mırrî. el-İnâye şerhu'lHidâye. 1-10 Cilt. Dârü'l-Fikr, ts.

Bardakoğlu, Ali. "Hanefi Mezhebi”. Türkiye Diyanet Vakfi İslâm Ansiklopedisi. 16/1-21. İstanbul: TDV Yayınları, 1997.

Bayder, Osman. Kurucu İmama Muhalefetin İmkan ve Sinırı -Hanefi Mezhebi Örneği-. Ankara: Maarif Mektepleri Yayınları, 2018.

Burhâneddin el-Buhârî, Burhânüddîn (Burhânü'ş-Şerîa) Mahmûd b. Ahmed b. Abdilazîz el-Buhârî el-Mergînânî. el-Muhîtu'l-Burhânî. thk. Nuaym Eşref Nûr Ahmed. 1-25 Cilt. Riyâd: Mektebetü'r-Rüşd, 2004.

Dâmad Efendi, Abdurrahmân b. Muhammed b. Süleymân. Mecma'u'l-enhur fí șerhi Mülteka'l-ebhur. 4 Cilt. Beyrut: Dâru'l-Kütübi'l-İlmiyye, 1998.

Ebü'l-Leys es-Semerkandî, Ebü'l-Leys Nasr b. Muhammed b. Ahmed b. İbrâhîm es-Semerkandî. 
Kitâbü’n-Nevâzil. İstanbul: Süleymaniye Kütüphanesi, Fatih, 2414.

Ekinci, Ekrem Buğra. Sultan Abdülhamid'in Son Zevcesi Behice Sultan'la Altı Ay. İstanbul: Timaş Yayınları, 2017.

Gyunesh, Ahmed Salih Ahmed. Burhaneddin el-Mergînânînin "Muhtâratu'n-nevâzil" Eserinin Edisyon Kritiği. Konya: Selçuk Üniversitesi Sosyal Bilimler Enstitüsü, Yüksek Lisans, 2010.

Haddâd, Radıyyüddîn Ebû Bekr b. Alî b. Muhammed el-Haddâd. el-Cevheretü’n-neyyire 'alâ Muhtasari'l-Kudûrî. 1-2 Cilt. el-Matbaatü'l-Hayriyye, 1322.

Hakim, Muhammad Akram. Cemâleddin el-Konevînnin (V. 770/1369) el-Gunye fi'l-Fetâvâ Adlı Eserinin Tahkik ve Değerlendirilmesi. Konya: Necmettin Erbakan Üniversitesi, Sosyal Bilimler Enstitüsü, Doktora Tezi, 2016.

İbn Âbidîn, Muhammed Emîn b. Ömer b. Abdilazîz el-Hüseynî ed-Dımaşkî. Nesemâtü'l-eshâr 'alâ Iffâdati'l-envâr. Pakistan: İdâratü'l-Kur'ân ve'l-'Ulûmi'l-İslâmiyye, 3. Basım, 1997.

İbn Âbidîn, Muhammed Emîn b. Ömer b. Abdilazîz el-Hüseynî ed-Dımaşkî. Reddü’l-muhtâr ale'dDürri'l-muhtâr şerhi Tenvîri'l-ebsâr. thk. Âdil Ahmed Abdülmevcûd - Ali Muhammed Muavviz. 1-10 Cilt. Riyad: Dâru Âlemi'l-Kütüb, 2003.

İbn Nüceym, Zeynüddîn b. İbrâhîm b. Muhammed el-Misrî. el-Bahrü'r-râik şerhu Kenzi'd-dekâik (Minhatü'l-hâlik ile birlikte). 1-8 Cilt. Dârü'l-Kütübi'l-İslâmî, 2. Basım, ts.

İbnü'l-Hümâm, Kemâlüddîn Muhammed b. Abdilvâhid b. Abdilhamîd es-Sivâsî el-İskenderî. Fethu'lkadîr. 1-10 Cilt. Dârü'l-Fikr, ts.

Kâdîhân, Ebü'l-Mehâsin Fahrüddîn Hasen b. Mansûr b. Mahmûd el-Özkendî el-Fergânî. el-Fetâva'lHâniyye (el-Fetâva'l-Hindiyye ile birlikte). 1-6 Cilt. Bulak: Matbaatü'l-Kübra'l-Emîriyye, 1310.

Kallek, Cengiz. "Telcie". Türkiye Diyanet Vakfi İslam Ansiklopedisi. 40/397-400. İstanbul: TDV Yayınları, 2011.

Kâsânî, Alâüddîn Ebû Bekr b. Mes'ûd b. Ahmed el-Kâsânî. Bedâi 'u's-sanâi fî tertîbi'ş-şerâi'. 1-7 Cilt. Dârü'l-Kütübi'l-İlmiyye, 2. Basım, 1986.

Kaya, Eyyüp Said. Mezheblerin Teşekkülünden Sonra Fıkhî İstidlal. İstanbul: Marmara Üniversitesi Sosyal Bilimler Enstitüsü, Doktora, 2001.

Kefevî, Mahmûd b. Süleymân el-Hanefî el-Kefevî. Ketâibü a'lâmi'l-ahyâr min fukahâi mezhebi'nNưmâni'l-muhtâr. thk. Saffet Köse vd. 1-4 Cilt. İstanbul: Mektebetü'l-İsşâd, 2017. 
Ateş, Hanefî Mezhebine Göre Talakın Gizlenmesi Durumunda İddetin Başlangıcı: Meşâyih Fetvasının Müftâ Bih ...

Köse, Saffet. "Hiyel”. Türkiye Diyanet Vakfi İslam Ansiklopedisi. 18/170-178. İstanbul: TDV Yayınları, 1998.

Köse, Saffet. İslâm Hukuku Açısından Kanuna Karşı Hile ve Hile-i Şer'iyye. İstanbul: Hikmetevi Yayınları, 2. Basim, 2020.

Kudûrî, Ebü'l-Hüseyn Ahmed b. Ebî Bekr Muhammed b. Ahmed el-Kudûrî. Muhtasarü'l-Kudûrî. thk. Kâmil Muhammed Muhammed Uveyzâ. Dârü'l-Kütübi'l-İlmiyye, 1997.

Kureşî, Ebû Muhammed Muhyiddîn Abdülkâdir b. Muhammed. el-Cevâhiru'l-mudiyye fî tabakâti'lHanefiyye. thk. Abdülfettâh Muhammed el-Hulv. 1-5 Cilt. Cîze: Hicr li't-Tıbâ‘a ve'n-Neşr, 2. Basım, 1993.

Mergînânî, Ebü'l-Hasen Burhânüddîn Alî b. Ebî Bekr b. Abdilcelîl el-Fergânî el-Mergînânî. el-Hidâye fi şerhi Bidâyeti'l-mübtedî. thk. Talâl Yûsuf. 1-4 Cilt. Beyrut: Dâru İhyâi't-Türâsi'l-Arabî, ts.

Mevsilî, Ebü'l-Fazl Mecdüddîn Abdullâh b. Mahmûd b. Mevdûd el-Mevsilî. el-i̇htiyâr li-ta'lîli'l-Muhtâr. thk. Mahmud Ebû Dakîka. 1-4 Cilt. Matbaatü'l-Halebî, 1937.

Meydânî, Abdülganî b. Tâlib b. Hammâde el-Meydânî el-Guneymî ed-Dımaşkî. el-Lübâb fî şerhi'lKitâb. thk. Muhammed Muhyiddîn Abdülhamîd. 1-4 Cilt. Beyrut: el-Mektebetü'l-i̇lmiyye, ts.

Molla Hüsrev, Muhammed b. Ferâmurz. Dürerü'l-hükkâm şerhu Gureri'l-ahkâm. 1-2 Cilt. Dâru İhyâi'lKütübi'l-Arabiyye, ts.

Serahsî, Ebû Bekr Şemsü’l-eimme Muhammed b. Ebî Sehl Ahmed es-Serahsî. Kitâbül-Mebsût. Beyrut: Dârü'l-Marife, ts.

Şelebî, Şihâbüddin Ahmed b. Muhammed b. Ahmed eş-Şelebî. Hâşiyetü'ş-Şelebî alâ Tebyîni'l-hakâik. 16 Cilt. Bulak: el-Matbaatü'l-Kübra'l-Emîriyye, 1313.

Şeybânî, Ebû Abdillâh Muhammed b. el-Hasen b. Ferkad eş-Şeybânî. el-Asl. thk. Muhammed Boynukalın. 1-12 Cilt. Beyrut: Dâru İbn Hazm, 2012.

Şürünbülâlî, Ebü'l-İhlâs Hasen b. Ammâr b. Alî eş-Şürünbülâlî el-Vefâ̂i el-Mırrî. Gunyetü zevi'lahkâm fí buğyeti'd-Düreri'l-ahkâm. 1-2 Cilt. Karaçi: Mir Muhammed Kütüphane, ts.

Tuychibaev, Abdumalik. Ahmed b. Musa el-Keşşı̂nin Mecmu'u'l-hevâdis ve'n-nevâzil ve'l-vâktât Adlı Eserinin Tahkik ve Değerlendirilmesi. Ankara: Ankara Üniversitesi, Sosyal Bilimler Enstitüsü, Doktora Tezi, 2021.

Uğur, Seyit Mehmet. "Hanefî Mezhebinde Müftâ Bih Görüşün Belirlenmesinde Meşâyihın Rolü”. 6. 
Ateş, Beginning of 'Idda ( The Waiting Period After Divorce) in Case of Hiding Divorce According to Hanafi Sect

Türkiye Lisansüstü Çalışmaları Kongresi-Bildiriler Kitabı III. 99-112. İstanbul: İlem, 2017.

Uğur, Seyit Mehmet. Hanefilerde Mezhep İçi Tercih ve Usulü. İstanbul: M.Ü. İlahiyat Fakültesi Vakfı Yayınları, 2019.

Zeylaî, Ebû Muhammed Fahruddîn Osmân b. Alî b. Mihcen b. Yûnus es-Sûfî el-Bâriî ez-Zeylaî. Tebyînü'l-hakâik şerhu Kenzi'd-dekâik (Hâşiyetü'ş-Şelebî ile birlikte). Bulak: el-Matbaatü'lKübra'l-Emîriyye, 1313.

el-Fetâva'l-Hindiyye. 1-6 Cilt. Bulak: Matbaatü'l-Kübra'l-Emîriyye, 1310. 
Ateş, Hanefî Mezhebine Göre Talakın Gizlenmesi Durumunda İddetin Başlangıcı: Meşâyih Fetvasının Müftâ Bih ...

\section{Beginning of 'Iddah ( The Waiting Period After Divorce) in Case of Hiding Divorce According to Hanafi Sect: Process of Returning of the Mashāyikh's Fatwa to "Mufta Bih"}

\section{Dr. Mustafa ATEŞ}

\section{Extended Summary}

According to Islamic law, talāq is defined as the termination of the marriage with the husband's unilateral declaration and specific words. Accordingly, it is valid for the husband to divorce his wife without informing, it is not necessary for the wife to be aware of the divorce for the talāq to take place. 'Iddah, one of the results of talāq, means the time that the woman has to wait in case the marriage ends. 'Iddah begins after talāq in case of divorce and after death in case of death. However, the fact that talāq is suitable for concealment, as it occurs with a unilateral declaration of will, allows some savings that are normally prohibited. One of the issues discussed in this context is the issue of marriage with the fifth woman and the sister of the divorced woman. According to Islamic law, it is not possible for a person to marry his fifth wife or his wife's sister. Again, in relation to this, a man who has four wives and divorces one of them and wants to marry another woman, or who wants to marry the sister of his divorced wife, must wait for the ciddah of his divorced wife before getting married. A person who has four wives and claims that he has divorced one of them before and that the period of iddah has expired can marry another woman or the sister of his wife, whom he claims to have divorced, without waiting for the ciddah period. Because he states that he divorced his wife before the 'iddah period. Therefore, in this case, his wife's 'iddah period also expires. Again, if it is accepted that the ciddah starts from the talāq in case the talāq is hidden, a person who has four wives can divorce one of them and marry another woman when his 'iddah expires, although he does not tell which one he has divorced. As a matter of fact, after Sultan Abdülhamid II's death, the inheritance case, in which each of his nine remaining wives claimed marriage, has been interpreted in this way by some legal historians. One of the issues related to the concealment of talāq is the possibility of collusion. The possibility of collusion, which comes to the fore when a person who is sick with death says that he has divorced his wife before and that the period of ciddah has been completed, has caused a disagreement within the madhhab about when the ciddah will start in the aforementioned issue. A husband who agrees with his wife to achieve a certain purpose may say that he divorced his wife, for example, five years ago. Considering this example, if it is accepted that ciddah started after talāq, there may be some purposes that the husband and wife may want to achieve illegally by colluding. For this reason, the mashāyikh gave a fatwa that 'iddah would start from the moment of acknowledgement, even if the woman approved the acknowledgement in such 
cases, due to the possibility of collusion and to prohibit concealing the talāq. This fatwa became a rule in the madhhab. It is understood that the fatwa stating that if the tala $q$ is hidden, the ciddah will start from the time of acknowledgement, has become a rule in the madhhab at the latest as of the sixth Hijri century. Since this century, no different views or objections have been encountered on the subject. It is seen that especially Marghinnānī, Kāài Khān, and Burhān al-Dīn al-Bukhārī were influential in the adoption of the fatwa as a rule in the sect. On the other hand, the statement made by al-Sughdi about the zāhir al-riwāya view was considered important in that it showed that the aforementioned fatwa was not contrary to the zāhir al-riwāya, and it was mentioned on this occasion in many places. According to alSughdī, the view in al-Mabsut that ciddah will start from the time of talāq is attributed to the fact that the husband and wife live separately from the date of talāq. The separation of husband and wife indicates divorce, and the possibility of collusion disappears However, suppose the husband and wife continued to live together. In that case, it is understood that both of them lied, and the aforementioned acknowledgement and the woman's approval are not taken into account. In the research, it was seen that this fatwa, which was transmitted in relation to the mashāyikh, was first attributed to Abu Bakr al-Iskāf al-Balkhī within the framework of accessible sources. The fact that the aforementioned fatwa was mentioned in relation to the "Mashāyikh al-Balkh" in the following periods indicates that Abu Bakr al-Iskāf had a significant influence on the adoption of the fatwa. However, it is of course possible that the jurists of other regions brought up the same fatwa at different times. On the other hand, considering that Abu Bakr al-Iskāf lived in the fourth Hijri century, it can be said that the fatwa became a rule at least two centuries later.

Keywords: İslamic Law, Mashāyikh, Fatwa, Divorce, 'Iddah. 